\title{
Family and Social Acceptance of Transgender Women in the Midst of Stigmatization in Indonesia
}

\author{
Momy A. Hunowu \\ Department of Sociology of Religion \\ IAIN Sultan Amai Gorontalo \\ Gorontalo Indonesia
}

\begin{abstract}
Stigmatization towards transgender women in Indonesia has become more severe that cause them to be more marginalized. They were not only driven out by their families, but also rejected by the society. This paper aims to analyze the transgender women 's efforts to show their existence so that they can be accepted by the family and society. The research was conducted with a qualitative approach. Data collection was done by in-depth interviews and observations to seven participants at the local level and online data collection to participants at the regional and global levels. The data were analyzed through three stages of data analysis, namely data reduction, data display and data verification to meet the conclusion. The result shows that transgender women can prove their existence through their socio-economic role so that families and communities have no reason to reject them.
\end{abstract}

Key Words: Social acceptance, Transgender existence, Stigmatization, Socio-economic role.

\section{INTRODUCTION}

In Indonesia, the existence transgender women are not always rejected and their existence can be accepted by the family and society in certain context. The common causes of the rejection towards them are the negative stigma of transgender women which has become common belief [1] and public has not welcomed things that are considered abnormal [2]. Historically, the public acceptance and respect for transgender women has taken place during the ancient Javanese kingdom when transgender women were part of the king's servants who had magical and political powers so that they got important positions and were given special rights [3]. Today, there are a numerous transgender women who have benefited the society and been appreciated by the government [4-5].

There have been many previous studies on the rejection of the transgender women existence. The focus of these researches can be classified into several groups. First are the researches that focus on the area of rejection such as in the public space [6], politics [7], sport [8-9] and religion [2]. One of the reasons behind the social rejection is the social and religious deviations committed by transgender women such as engaging in nightlife [10], etc. Second, the previous studies showed the resilience of transgender women [11-12] that were caused by much rejection happened to them [13]. Third, there are previous studies on the, and rejection of LGBT [14]. Public acceptance of transgender women is still limited to work field [15]. The transgender women's sincerity to be involved in the development has raised legitimation from the government to their roles [4-5].

This paper is aimed to fill the gap of the previous studies the existence of transgender women who have received rejection from their families and society, and the limited acceptance of society in certain spaces. There were three questions raised in this study, namely (1) how is the existence of transgender women in the midst of negative stigma? (2) what factors influence public acceptance of transgender women? (3) what are the implications of public acceptance on the social life of transgender women?. These three questions were directed to the understanding that the existence of transgender women in the midst of negative stigma does not completely lead to social rejection. There are transgender communities which can be accepted by both families and society due to certain factors. In other words, this paper aimed to examine the possibility of acceptance and respect for this minority group the midst of discrimination and stigmatization. 
This paper was written based on an argument that negative social stigma about the existence of transgender women cannot be generalized. By showing their socio-economic existence, transgender women can be accepted and appreciated by the society at the local, regional and global levels despite the increasingly widespread stigmatization of transgender women

\section{LITERATURE REVIEW}

In this paper, there are three main concepts which become the foundation in the discussion and analysis, that are: concept of discrimination and rejection, concept of transgender women's existence, and concept of transgender women's stigmatization.

\subsection{Discrimination and Rejection}

Discrimination is an unequal and unfair treatment that distinguish individuals or groups based on race, religion, ethnicity, religion, or status of social classes. Discrimination portrays an action from the majority as dominant group against the minority as weak group, so that the behavior looks immoral and undemocratic[16]. The dominant group who rejects the existence of transgender women argues that becoming transgender is a deviation. In contrast, the concerned group believes that being transgender is not an option but a gift from God. It is unfair when they are discriminated against their destiny[17].

Discrimination against transgender women goes with rejection of their existence as a social construction that creates prejudice, stereotypes, and hatred because they are considered as deviations from social values and norms[18]. Prolonged discrimination is not only in the form of bullying but also in the form of sexual harassment [19]. Other forms of discrimination that are often seen take place in job recruitment and promotion, verbal harassment, exclusion, bullying and given certain nickname such as 'sissy', violence, neglect and intimidation[20]. This discrimination and rejection make transgender women to be increasingly marginalized in social life.

\subsection{Discrimination and Rejection}

The concept of transgender is closely related to the problem of a person's gender identity. The members of this group identify their identity and gender differently from their biological gender [21]. In general, the existence of minority groups such as LGBT in Indonesia is still a dilemma. Some people see transgender community as a form of violation of legal, religious and moral norms. On the other hand, the others think that the LGBT community is an inseparable part of society [22]. In the perspective of transgender women, what happens to their female-oriented selves is a psychological symptom that is hardly neglected. Their transgender desires arise spontaneously[5]. The phenomenon of transgender is treated differently throughout human history. Historically, the existence of transgender women has an integral position in certain cultures in Indonesia[24]. The transgender women occupied the position of royal servants who have magical and political powers, and they were given privilege[3]. Even in USA, transgender people are accepted and given military role[6]. The acceptance towards transgender women is usually based on a human rights belief. Whereas, the rejection is based on the assumption that transgender is a form of deviation from human nature [25].

Among LGBT community, transgender is the most vulnerable to violence because of their physical appearance are more noticeable than lesbians, gays and bisexuals. This contrast of body and behavior makes transgender women are considered strange and excluded from society through homophobic stigmatization[26] In this relation, transgender women still have a role in the society like other gender groups. A transgender person can act as the head of the household[27] or a member of the military [6]. In the development sector, transgender women have participated financially in village development [28]. Information about the involvement of transgender women in every aspect of life is not in line with the negative stigma that is increasingly widespread.

\subsection{Stigmatization of Transgender}

Stigma is caused by the belief in something fatal as a result of immoral behavior that is unacceptable to society. The stigma is reflected in cynicism, excessive fear, and negative experiences so that deviant behavior such as in the case of HIV/AIDS deserves punishment for their own actions[29].

Individuals who are stigmatized are generally associated with social illness such as free sex, drug user, homosexual, etc. Transgenders are among those who receive this negative stigma. This has backfired on them who are considered 'bad person' by the society [30]. As a result of this negative widespread stigma, transgender women experience increasing rates of abuse, violence, and mental health problems[31]. Doing positive action is a way to reduce negative stigma. The positive actions of transgender women on an ongoing basis will have implications for public acceptance of their existence[32]. 


\section{METHOD}

The relation between the existence of transgender women with social acceptance in this paper were described by qualitative research from primary and secondary data. Primary data were collected from the participants in Makassar, Gorontalo and Manado, who has proved their existence in the middle of negative stigma. The secondary data were collected online, both from journal or online media which discuss about transgender celebrities in Indonesia and abroad. Both primary and secondary data were used as the foundation of analysis for the relation between the existence of transgender in the stigmatization and the acceptance of family and society to this minority group.

This research involved the participants into two groups, that are the transgender women who change their appearance to look like women and those do maintain their appearance as men. Both groups try to show their existence by maintaining their career in the middle of discrimination and stigmatization. This paper analyzed the relation between their existence in the negative stigmatization and the acceptance from family and society. Interview and observation were chosen as methods to collect information on how they are treated by their surroundings. The participants were classified based on their economic independence and stability. Then, they are identified based on the acceptance or rejection from family and society.

The stages in this research started by collecting observational data and interviews with transgender participants, families and communities. First, the observation data was to see how the acceptance of the family and society towards the existence of transgender was. Second, data from interviews was to explore the existence of transgender women in the midst of widespread negative stigma. These various data become the foundation for analyzing the correlation between the existence of transgender women in the midst of negative stigma and acceptance by family and society.

The data was then analyzed through three stages of data analysis. First, data reduction was done to arrange the data systematically, especially thematically. Secondly, the data was displayed with the aim to present research results in the form of narration of observations and interview excerpts. Third, the data was verified as a stage of data inference, especially following the trend of the data obtained. Then, the processed data went through descriptive methods and were displayed in tables. Description of the data as the basis for the interpretation process carried out contextually. Analysis stages and the analytical techniques then led to conclusions on the correlation between the existence of transgender women in the midst of the current of widespread negative stigma with family and social acceptance

\section{RESULT}

Define abbreviations and acronyms the first time they are used in the text Metal Matrix Composite (MMC). Do not use abbreviations in the title and abstract unless they are unavoidable.

\subsection{The Existence of Transgender Women in Indonesia}

According to the data Republic of Indonesia Ministry of Health in 2014, transgender women who are at risk of being affected by HIV/AIDS was estimated at 597 thousand women [33]. However, this data cannot be generalized that all transgender women are deviated and disturb the society. There are two categories of transgender women defined in this paper; first, transgender women who look like women, both in the way they dress and change the physical appearance; and second, transgenders who still look like men but their body movements are feminine, where in Gorontalo it is called as tabuwa-buwa or women-look alike.

Mayka is law school graduate from Hasanuddin University, Makassar who decided to change her appearance as woman after she graduated. Since she was a child, Mayka has been an active member of Muslim Youth Group, and was widely known in her

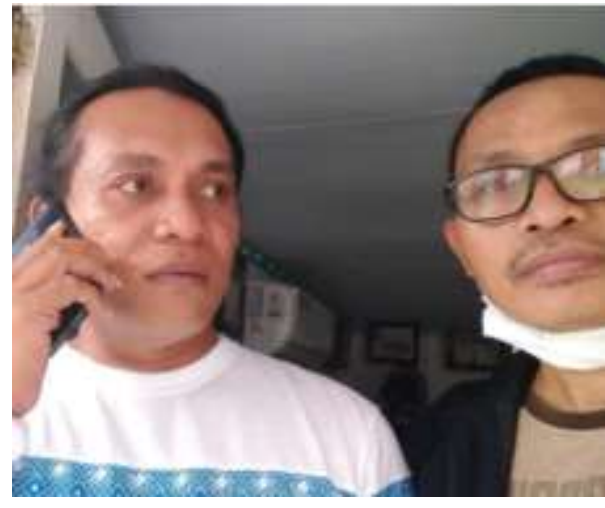
peers. She was a high achiever. After she decided to be a woman, she works as model, make up artist and endorser. Although she is a transgender, she mingles with the member of society in general and not with transgender community. Her attractive appearance makes her to behave like the real woman. She has full support from her family who has military background.

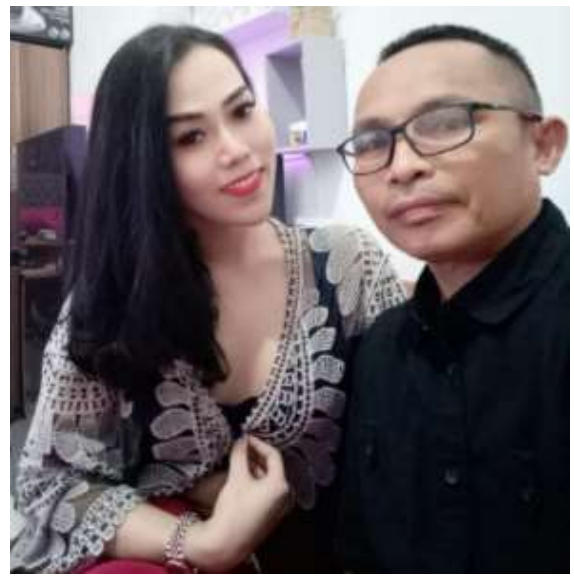

Figure 1.Mayka and the researcher

Figure 2. Gusye and the researcher 
Gusye is a transgender from Gorontalo who has been expelled from family. Then, Gusye moved to the older sibling's house. Although Gusye is known as transgender, Gusye never change the appearance but only the gesture and voice. Gusye did not finish their school because of bullying. However, Gusye proved their persistency and skills to finally open their own bridal business that has five employees. Gusye's business also serves funeral event such as decorating coffin and cultural accessories for 40-day Quran recitation for the deceased. Gusye's role in the society leads to social acceptance..

Chaca is a singer and make-up artist in Makassar. She has changed her appearance to look like woman, but her voice is still man's voice. She lives independently by renting a house in the downtown. She is busy with her job as singer and make-up artist. She does not befriend the lower-class transgender who works as prostitute. In the beginning of her decision, Chacha was opposed by her 8 siblings. Her mother support is a thing that make her survive until today. Now, she also helps to support the economy of her family.

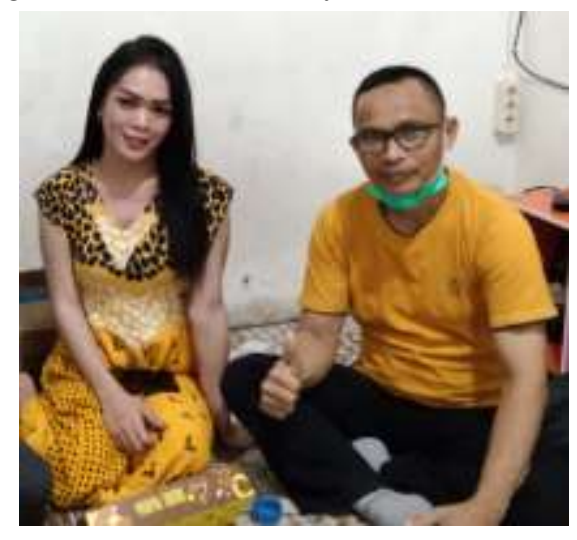

Figure 3. Chaca and the researcher

Another transgender in this paper is Felicia. She is from Gorontalo and recently changed her appearance to look like woman. Since she was a child, she looks like normal man and there was no sign of transgender behavior. It was the environment who changed her. As stated by[34] the main factor of the change in sexual orientation is the environment. After graduated from high school, she befriended transgender community until she was influenced. She changed her appearance, hairstyle, and medical treatment to make her breast developed. She works as a shop attendant in a clothing store. Her family does not drive her away because her older sibling uses her piece of land for business. Her family are afraid that Felicia will take her land over if they reject her.

Anti is a feminine figure who works as civil servant and has position as treasures in his workplace. Although he has feminine figure, he has two wives. He is accepted in the society because he is active in local mosque's activity as well as supporting the community. He receives bullying from his colleagues but still being accepted as member of society because he does not show any deviance.

The next participant is Emen from Makassar who tries to look like woman but her voice is still man's voice. Emen successfully built her own house from her work as beauty saloon's employee. When the researcher interviewed her, the builders was still completing her house which was around 12 × 8 meters. Although she is still single, she tries to live independently because she is rejected by some of her family.

The last participant is Koko from Manado. Kokos's built is like ordinary man, but has feminine side with shoulder-length hair. Koko opens laundry and griller-fish business. In maintaining the business, Koko is helped by the employees, some of them are transgender. Koko is well-accepted by the society for his friendly attitude

Table 1: Research Participants

\begin{tabular}{cccc}
\hline Participant & Education & Appearance & Activity \\
\hline Mayka & Bachelor & Female & Make-up artist/ model \\
\hline Chaca & High School & Female & Singer/ make-up artist \\
\hline Gusye & Elementary School & Male & Make-up artist/ bridal \\
\hline Felicia & High School & Female & Shop attendant \\
\hline Anti & Magister & Male & Civil servant \\
\hline Emen & High School & Female & Beauty salon employee \\
\hline Koko & High School & Male & Laundry and grilled-fish business
\end{tabular}

Table 1 showed that seven participants have different educational backgrounds, ranging from low education to higher education. Three women had their appearances to be beautiful and barely-recognized women, while the others maintain their looks as men. All participants have regular jobs that make them independent and can participate in social life. Because of their productive and normal behavior, they are well-received in their social environment. 
The rejection of transgender women who change their appearance to women happens when in the beginning of their change. It is common for them to even receive harsh treatment from the family. Their existence that shows independence and economic stability makes the family turn to support their existence

\subsection{Social Acceptance to Transgender Women's Existence}

Although the participants in this research have style and appearance like women, they are productive and do not violate social norms such as being a prostitute and infected with HIV/AIDS, etc. They have something that the family can be proud of and valued by the community. They are economically independent and choose normal jobs. Mayka, Chaca, Felicia and Emen dress up like women but they have permanent jobs, economically independent and have achievements. Gusye, Anti and Koko are three feminine men who don't change their appearance. Even though they get bullied from their friends but all three can fulfill their social roles. All transgender women have shown signs of femininity since childhood, but Felicia. This transgender woman, whose real name is Fery, was a normal masculine man, and suddenly became transgender woman. Initially, she received a strong rejection from her family, but because she had economic power, the family tried to accept her as a member of the family. As Felicia's older sibling admitted the following:

"I told my oldest sibling that let Felicia be with herself as transgender. Do not drive her out from our house. A piece of land owned by Felicia has become our business location. There's possibility if my oldest sibling keeps doing that, Felicia will ask us to move the business. Then my oldest sibling realized it and changed the treatment towards Felicia."

Similar to the statement above, Chaca also confessed:

"My parents have nine children, two of them are female and I am the third (while laughing). In the beginning, they treated me harshly; they threw my make up and hid my underwear. But my mother still supports me, she said that let me be what I want as long I can be independent and support my family financially."

All participants experienced the same thing, were once rejected and then accepted again. The result of this study indicates that family acceptance of the existence of transgender women is influenced by economic factors. Families turn to support and accept them because they are economically established and contribute to the family economy. Another factor that supports family and social acceptance is the behavior of participants who do not involve in violation to norms, in prostitution activities, HIV/AIDS and changing partners. To discuss clearly about the factors of family and social acceptance, it is shown in the table below:

Table 2: Factors of Social and Family Acceptance to Transgender Women

\begin{tabular}{lll}
\hline \multicolumn{1}{c}{ Participant } & \multicolumn{1}{c}{ Status } & \multicolumn{1}{c}{ Socio Economic Role } \\
\hline Mayka & In a relationship (with her boyfriend) & $\begin{array}{l}\text { Was active member of muslim youth organization, is active } \\
\text { at social event in the society }\end{array}$ \\
\hline Chaca & In a relationship (with her boyfriend) & $\begin{array}{l}\text { Entertain people by becoming a singer, work at make-up } \\
\text { artist, bread-winner for the family (mother) }\end{array}$ \\
\hline Gusye & Single & $\begin{array}{l}\text { Work as make-up artist and bridal service, involve in the } \\
\text { funeral event in the community }\end{array}$ \\
\hline Anti & Single & Own a land and family business \\
\hline Emen & Married (with females) & $\begin{array}{l}\text { Treasurer in his office, Member of Mosque Board, is active } \\
\text { member of the community }\end{array}$ \\
\hline Koko & Single & Beauty salon employee, bread-winner for the family \\
\hline
\end{tabular}

Table 2 showed that two aspects which strengthen family and social acceptance of the existence of transgender women are the good behavior and socio-economic role in the family and society. The deviant behavior of the most of the transgender women, such as easily changing partners and being involved in prostitution, is the main reason for the rejection of the family and society. As stated by Mayka;

"Although I am a transgender woman, I am not befriended with many transgender women. I want to be other normal female that have normal community. Usually, mingle with transgender women will receive offensive comment and treatment from the society." 
Similar to Mayka, Chaca also avoid transgender woman's community. Only Felicia who migle with her transgender womens' community, including to work as shop attendant because the influence of her friends. It is true that Felicia's neighbors do not reject her, but they feel pity towards her.

"I was quite shocked once I knew she changed from Fery, a handsome and quite male, who now looks beautiful with her shoulder-length hair. Her fair skin supports her feminine look with her dresses. In the beginning, I saw she has many transgender women who came to visit her, that then turns her orientation. But because she is nice and kins to the neighbors, we can only pity her and do not reject her. Her sibling used to fight her, but it was not for too long."

The piece of land that Felicia's own from her father's inheritance become her power to survive from family rejection. Thus, it can be concluded that socio-economic factor become the dominant factor in the acceptance of transgender women in family and society.

\subsection{Implication of Family and Social Acceptance}

Social acceptance of transgender women in social life further reduces the negative sigma of transgender people. This condition is an entry point to reduce the negative stigmatization and increase family and acceptance of transgender women. It is in accordance with Mayka, Chaca and Eman's experience who transform their appearance to look like women. Family and social acceptance motivates them to live a better life, such as take their career seriously and avoid deviant behavior.

Based on the participant's experience, it shows that the implications of family and social acceptance further improve the existence of transgender women. The number of transgender communities like this is still very limited, because it is still generally initiated by the upper-class transgender women. Meanwhile, the number of transgender women with deviate behavior that are rejected by society is still very large

\section{DISCUSSION}

The research result at the local level indicates that family and social acceptance of the existence of transgender women is due to the fact that they do not show deviat behavior but instead prove their capability in socio-economic value in the family and society. This condition allows transgender women to reach higher status from the lower-class society that are often harassed to a new social class that is recognized and respected by the society. At the regional level, there are many transgender women or feminine men who are well received by their families and society. Some of the close examples are Dorce Gamalama and Ivan Gunawan. Dorce Gamalama is praised by the Indonesian people as a top artist [35] and the feminine man Ivan Gunawan as a top artist and designer (detik.com). Both are accepted as members of the society because they have classy talents and skills in the entertainment world.

On a global level, people know the late Michael Jackson as an Afro-American man with high artistic talent. Even though he turned into a man with feminine look, Michael Jackson is still praised by the people because of his songs and choreography. Jackson was able to demonstrate high skills in singing and dancing [36]. Dreaming of following Jackson's success career in singing and danacing, many artists are trying to build their careers and fame by imitating Michael Jackson's choreography [37].

The acceptance of the family and the wider society towards the existence of transgender women in the midst of a widespread negative stigma has allowed transgender women to have a higher social class position. They are not only given feminine roles, but also in masculine roles[6]. Giving social space to transgender women actually had been practiced during the ancient Javanese kingdom[3]. The widespread stigmatization is the cause of degradation of transgender women's position, and make them being mocked. The rejection is mostly obtained by those who adhere to high moral traditionalism[8].

Feminine look and the desire to look like women is something hardly contained, is not artificial and comes spontaneously[23]. This side is the cause of feminine men to turn into women. These changes in behavior and appearance have brought transgender women to a world full of bullying. Those who do not fall into deviant behavior by showing their socio-economic existence have enabled them to be accepted by family and society. Family and social recognition of transgender women has a very positive impact on their social life[23]. Therefore, family and social acceptance of transgender women has implications for giving opportunities to transgender women to avoid negative situations. This is what[32] called as positive action, that the widespread negative stigma regarding the deviant behavior of transgender people further push them into discrimination and rejection. By doing positive action, it will allow the return of the privileges of transgender women as applied to ancient Javanese society [3].

\section{CONCLUSION}

Transgender women are well-received by the society when they can play their socio-economic role, both in the family and social environment. Developing talents and skills in the socio-economic field has turned bully into appreciation. 
Negative stigma occurs because transgender women ignore their socio-economic role. The negative stigma becomes positive not only caused by the themselves, but also by the support of the wider society. Discrimination and rejection of transgender women often occurs to them who have far deviate and violate social norms. This negative side is the most exposed to the public, so that it reinforces the negative stigma to all of them. The results of this study found that not all transgender women have a dark side and negative behavior. There are still many good and productive transgender women whose existence is needed by their families and society.

This research is still limited to family and social acceptance of transgender people who have the ability and skills to play their socio-economic role. Other important aspect that needs further research ids their position in politics and religion.

\section{REFERENCES}

[1] Fadi, V., \& Azeharie, S. S. (2020). Public Perceptions of Transgender Groups (Public Perceptions of Islamic Boarding School Transgender Groups). Connections, 4(1). https://doi.org/10.24912/kn.v4i1.6609

[2] Valencia Villy Mengko, Kandowangko, N., \& Lesawengen, L. (2016). Transgender Life in Manado City, (Transgender Life in Manado City). Acta Diurna Communications.

[3] Muhamad Alnoza, \& Dian Sulistyowati. (2021). The Construction of Ancient Javanese Society on Transgender Women in the 9-14th Century AD. AMERTA, 39(1). https://doi.org/10.24832/amt.v39i1.51-64

[4] Tanjung, F. (2021). Adaptation of Waria: Case Study of Waria Community in Pangkep District. (Adaptation of Waria: Case Study of Waria Community in Pangkep District) PREDESTINATION, https://doi.org/10.26858/predestinasi.v13i1.1631(Adaptation of Waria: Case Study of Waria Community in Pangkep District )

[5] Lewis, D. C., Tadlock, B. L., Flores, A. R., Haider-Markel, D. P., Miller, P. R., \& Taylor, J. K. (2021). Public Attitudes on Transgender Military Service: The Role of Gender. Armed Forces and Society, 47(2). https://doi.org/10.1177/0095327X19861737

[6] Khasan, M., \& Sujoko. (2018). Waria Coping Behavior: A Phenomenology Study of Waria Discrimination Cases in Surakarta. Journal of Psychological Science, 7(1), 99-106. (Waria Coping Behavior: Phenomenological Study of Transgender Discrimination Cases in Surakarta)

[7] Kartinaningdryani, I. (2019). Heteronormativity, LGBT Discourse and the Struggle of the Waria Community Against Stigma. Journal of Sociological Thought, 6(2). https://doi.org/10.22146/jps.v6i2.51587, (Heteronormativity, LGBT Discourse and the Struggle of the Waria Community Against Stigma )

[8] Flores, A. R., Haider-Markel, D. P., Lewis, D. C., Miller, P. R., Tadlock, B. L., \& Taylor, J. K. (2020). Public Attitudes about Transgender Participation in Sports: The Roles of Gender, Gender Identity Conformity, and Sports Fandom. Sex Roles, 83(5-6). https://doi.org/10.1007/s11199-019-01114-z

[9] Acklin, K. (2017). "Hurdling" Gender Identity Discrimination: The Implications of State Participation Policies on Transgender Youth Athletes' Ability to Thrive. Boston College Journal of Law \& Social Justice, 37(1).

[10] Awad, L., Elim, C., Dundu, A. E., \& Ekawardani, N. (2015). Differences In Knowledge Level And Attitude About Hiv/Aids In Waria Commercial Sex Workers And Waria Non-Commercial Sex Workers In Manado. City) E-CliniC, 3(1). https://doi.org/10.35790/ecl.3.1.2015.7477

[11] Chavanduka, T. M. D., Gamarel, K. E., Todd, K. P., \& Stephenson, R. (2021). Responses to the gender minority stress and resilience scales among transgender and nonbinary youth. Journal of LGBT Youth, 18(2). https://doi.org/10.1080/19361653.2020.1719257

[12] Matsuno, E., \& Israel, T. (2018). Psychological Interventions Promoting Resilience Among Transgender Individuals: Transgender Resilience Intervention Model (TRIM). Counseling Psychologist, 46(5). https://doi.org/10.1177/0011000018787261

[13] Andhiny, N. A. (2018). Social support for waria. Ahmad Dahlan University. 
[14] Katz-Wise, S. L., Rosario, M., \& Tsappis, M. (2016). Lesbian, Gay, Bisexual, and Transgender Youth and Family Acceptance. In Pediatric Clinics of North America (Vol. 63, Issue 6). https://doi.org/10.1016/j.pcl.2016.07.005

[15] Jones, S. E. (2020). Negotiating Transgender Identity at Work: A Movement to Theorize a Transgender Standpoint Epistemology. Management Communication Quarterly, 34(2). https://doi.org/10.1177/0893318919898170

[16] Fulthoni. (2009). Discrimination: The Pocket Book of Religious Freedom. (Discrimination: Pocket Book of Religious Freedom) Indonesian Legal Resource Center.

[17] Qibtiyah, A. (2015). Homosexuality Islam And Human Rights Perspectives. Musãwa Journal of Gender and Islamic Studies, 14(2). https://doi.org/10.14421/musawa.2015.142.197-210

[18] Ariba, F., \& Humsona, R. (2020). Student Discrimination Actions Against Transgenders (Qualitative Phenomenology of Discriminatory Actions by Sebelas Maret University Students against Transgenders), Journal of Development and Social Change, 3( 2).https://doi.org/10.20961/jodasc.v3i2.45767

[19] Klemmer, C. L. (2019). Transgender and Gender-Diverse Adolescents' Experiences of Violence, Depression, Anxiety, and Suicidal Ideation in the People's Republic of China. JAMA Network Open, 2(9), 10-12. https://doi.org/10.1001/jamanetworkopen.2019.11068

[20] Peng, K., Zhu, X., Gillespie, A., Wang, Y., Gao, Y., Xin, Y., Qi, J., Ou, J., Zhong, S., Zhao, L., Liu, J., Wang, C., \& Chen, R. (2019). Self-reported Rates of Abuse, Neglect, and Bullying Experienced by Transgender and Gender-Nonbinary Adolescents in China. JAMA Network Open, 2(9), 1-12. https://doi.org/10.1001/jamanetworkopen.2019.11058

[21] Jasruddin, J., \& Daud, J. (2015). Transgender in Public Perception. EQUILIBRIUM: Journal of Sociological Education, 3(1). https://doi.org/10.26618/jps-postkrit.v3i1.509

[22] Sujana, I. N., Setyawati, K. A., \& Ujanti, N. M. P. (2018). the Existence of the Lesbian, Gay, Bisexual and Transgender (Lgbt) Community in the Perspective of a State Based on Pancasila. Pulpit of Law - Faculty of Law, Gadjah Mada University, 30(1), 126. https://doi.org/10.22146/jmh.28655

[23] Safri, A. N. (2016). Family Acceptance of Waria or Transgender (Case Study of Waria/Transgender at the Al-Fatah Waria Islamic Boarding School Yogyakarta). Nizham, 05( 01), 26-41.

[24] Masnun, M. (2011). Waria and Prayers for Reinterpretation of Jurisprudence for Waria. Musãwa Journal of Gender and Islamic Studies, 10(1), 123-134. https://doi.org/10.14421/musawa.2011.101.123-134,

[25] Afif, M. B. (2019). Islam and Transgender (A Study of Hadith about Transgender). International Journal of the Islamic Archipelago, 7(2), 185-189. https://doi.org/10.15575/ijni.v7i2.6138

[26] Oki Rahadianto Sutopo. (2019). Journal of Sociological Thought Volume 6 No. 1, January 2019. Journal of Sociological Thought, 6(1).

[27] As'ad, \& Turofiah, H. (2019). Transgender Self-Concept as Head of Household. Maddah, 1(1).

[28] Pratiwi, D., \& Kolopaking, L. M. (2017). Leaders Influence on Productivity of Migrant Transvestites Community and Transvestites did in Rural Development. Journal of Communication Science and Community Development [JSKPM], 1(3).

[29] Shaluhiyah, Z., Musthofa, S. B., \& Widjanarko, B. (2020). Public Stigma to People Living with HIV/AIDS. National Journal of Public Health, 9(4), 333-339. http://journal.fkm.ui.ac.id/kesmas/article/view/740

[30] Liamputtong, P. (2013). Stigma, Discrimination and Living with HIV/AIDS; A Cross-Cultural Perspective. Springer Science and Business media 415.

[31] Boccanfuso, E., White, F. A., \& Maunder, R. D. (2021). Reducing Transgender Stigma via an E-contact Intervention. Sex Roles, 84(5-6). https://doi.org/10.1007/s11199-020-01171-9

[32] Cipriadi. (2017). Rational Actions Of The Waria Community To Avoid Negative Stigma In Community. Sociologique, 5(2), 66-75. http://jurnalfis.untan.ac.id

[33] Damayanti, R. (2015). Transgender Views on Gender Status and Human Rights Equality in Jakarta, Bogor, Depok and Tangerang. https://www.kemenpppa.go.id/lib/uploads/list/0ea2c-1-laporan-lgbt-transgender-.pdf 
[34] Kushandarwati, S. (2019). Which Affects Changes in Physical Appearance of the Cendana Waria Family Group in South Sinjai Regency, (Which Affects Changes in Physical Appearance of the Cendana Waria Family Group in South Sinjai, Sinjai Regency.). Journal of Chemical Information and Modeling, 53(9).

[35] Davies, S. G. (2016). Indonesia's anti-LGBT panic. East Asia Forum Quarterly, 8(2), 8-11. https://doi.org/10.3316/informit.337964851307684

[36] Valle, M. E. Del, \& Smit, R. (2021). Moonwalking together: Tracing digital memory work on Michael Jackson. Convergence. https://doi.org/10.1177/13548565211003878

[37] Aterianus-Owanga, A. (2019). 'They don't care about us': representing the black postcolonial subject through the appropriation of Michael Jackson in Gabonese urban dance. Journal of African Cultural Studies, 31(3). https://doi.org/10.1080/13696815.2016.1266464 